\title{
Nasopharyngeal Cancer pT3 TNM Finding v7
}

National Cancer Institute

\section{Source}

National Cancer Institute. Nasopharyngeal Cancer pT3 TNM Finding v7. NCI Thesaurus.

Code C88969.

Nasopharyngeal cancer with tumor involving bony structures of skull base and/or

paranasal sinuses. (from AJCC 7th Ed.) 